\title{
DETERRITORIALIZE YOURSELF! (Four Meta-Musical VignetTes FOR JOHN RAHN)
}

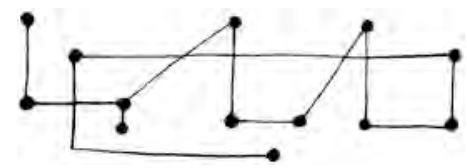

\section{CHRIS STOVER}

T MADE MY FIRST DeEP DIVE INTO BOTH Deleuze and Guattari and J.K. 1 Randall's work at around the same time, and through the same source: John Rahn's seminars on analytical personae and critical theory at the University of Washington in the mid-2000s. It was also in one of these seminars that I first began thinking seriously about how one might go about critically, analytically, theoretically, and politically engaging musical improvisation, as well as, more generally, how to think musically: that is, how to make thinking about music be more like music. I In order to clarify this last point, we might read four statements of John's alongside one another:

1. All discourse is "committed" to forming the world that it is about, so that it behooves the musician to make discourse about music like music, at least in the essential quality of rich particularity, and perhaps in all five of Nelson Goodman's "symptoms of the aesthetic" ...: semantic density, syntactical density, relative repleteness, exemplification, and multiple and complex reference. ${ }^{2}$ 
2. At the in-time extreme is an obsessive concern for the way in which, at every musical time, events immediately following that time grow out of events preceding that time. Such an explanation would consist of as many explanations as there are moments of musical time in a piece ... plus an explanation of the way all soexperienced piece-moments integrate into the entire piece. ${ }^{3}$

3. [following a select list of Heraclitus aphorisms] Musicians, he is speaking to us! The vagabonds of the night, the magicians, the bacchantes, the inspired! Clearly this is a different voice. ... Music flows, and swirls madly. 4

4. The advantage of semigroups and monoids over groups as a general model for machines is that not all machines can run backwards. Indeed, if we want to model musical acts as taking place in irreversible time, we will need to escape groups and inhabit monoids. ${ }^{5}$

Among many other take-aways, these maxims suggest to me a temporal effervescence, a commitment to understanding (and describing) music from within the ongoing practice of its enactment, a productive conflation of rational and mystical, and an attitude toward transformational thinking that escapes both the ontological fixity of Being and the formalist apparatus of homomorphic group functions. ${ }^{6}$ It is important to note that John in no way is taking a hard line with any of the positions articulated or implied in these quotes; each is intended as an image of thought, a provocation to get us thinking about how we think about music, to imagine other perspectives and refine the ones we're already engaged in. Time and change (and discourse about time and change): these are the themes that have animated the way I think about doing music theory.

What follows are four loosely related meta-musical vignettes, nominally about theorizing music-improvisation (and, to a degree, about Deleuze), but ducking and weaving through many ancillary themes, all rhizomatically connected, but also all forming a single quasi-improvisational narrative.

\section{Improvisation AND BECOMING-OTHER}

It is not so much working together to make something new out of the old but, rather, the more solitary act of "standing-within" the 
old, occupying it in such a way that its own opening onto being or "thrust into the Open" is preserved. If there is a collaborative dimension to improvisation it is not empathic but closer to what Heidegger describes as the "unsociability" of "Being-with."7

Improvised musical expression is an ongoing process of becomingother. We can speak of the becoming-other of music as a purely sonic phenomenon, as the way in which the sonic materiality of a collective musical expression (the music, in its process of becoming) transforms over time. In Deleuzian terms, this proceeds by way of a series of actualizations of the virtual openness of what at any moment could be, and which every moment opens onto. Another way to say this is that the event of an action enacts a becoming-actual of some bundle of virtual forces, all already there-already real-and partially constituting any now-present event. Events/actions repeat, each different, each a lively process of newly constituting affective connections. For Deleuze, the novelty of the newly-constituted context is precisely what repeats: the only thing that returns eternally is difference. For Rahn, this amounts to a "repetition within a larger thing whose telos is not given ... but is in the process of being formed." 8 The question for both Deleuze and Rahn involves the nature of the moments that constitute that larger thing; in other words, in musical discourse, how any given musical expression transforms: in each production of a new living present, what kinds of selections are made, what kinds of temporally-directed affective relations adhere, what kinds of desiring machines assemble in what kinds of ways to produce what kinds of individuating differentiations, and how do those procedures repeat to produce new differences, new becomings?

We can also speak of our participation in a singular instantiation of the music's becoming-other, during the time of its unfolding, "right where the musical action really is." $\mathrm{I}$ am interested in theorizing that participation, in part to refract the implications of becoming-other enacted within processes of music-improvisational interaction back toward the emergent identity of the individuating participant. This participant can be overtly involved in music-making (as, say, a performer in a musical ensemble) or less overtly so (as an audience member, for example). A conventional account of musicking roles would describe the former as an agent of active production and the second as a participant in a more passive, receptive engagement. A Deleuzian account redistributes these terms: both performing and listening involve active and passive actions that draw actual events and virtual forces into one another in mutually constitutive acts. ${ }^{10}$ Both are productive: of 
relations, of machinic couplings, of desire. ${ }^{11}$ Both active events and the production-assemblages that engender them are, however, founded on passive conjunctions: on the double movements of affective relations or of the machinic couplings through which identities are formed. Identity here refers doubly, irreducibly, to the productive bodies of musicking subjects-in-formation and to the musical expressions with which they form assemblages. To become a musicking body is to engage in a proliferating series of relations with these human and sonic agents. ${ }^{12}$

In a push against the kinds of utopian claims often made on behalf of improvised music, Gary Peters argues that collaborative improvisation may not be as empathetic as some of its champions would suggest, that there is less cooperation, less active, responsive listening and less of a discernible movement toward a common goal than a work-oriented analyst might hope for. ${ }^{13}$ This is not intended as a critique of improvised music itself; rather, Peters seeks a novel understanding of what it is that improvising musicians do in collective settings; one that does not overdetermine empathy as an ontologizing force, that does not depend on causal or teleological conceptions of form or process, and that sidesteps aesthetic narratives that attempt to ascribe value based on those conceptions. Peters's Heideggerian "being-with" is, instead, a being-alongside without an explicit motivation toward a shared goal (or even any goal at all). Heidegger insists that "empathy" does not first constitute Being-with; only on the basis of Being-with does 'empathy' become possible." l4 As always with Heidegger, we should read his scare quotes with a strong degree of finger-wagging sarcasm15_ "empathy" is not even what Heidegger is theorizing (and may not, according to his account, even be a thing); at any rate, Heidegger (and Peters) is more interested in a kind of primordial being-alongside that resonates with what I would call preconscious, affective conduits between co-constituting bodies.

Peters's claim is a foil to the kinds of critical evaluations of improvised musical expressions that use criteria intended for considering "works" as structurally cohesive products-Adorno's critique of jazz is most famous in this regard, but Peters also engages positions expressed by Boulez, Berio, and others. ${ }^{16}$ As Peters admits, in such structure-seeking analyses, improvised music necessarily falls short. But this is the point: to argue that improvised music does not hold up to scrutiny under some methodological lens is not to find the music lacking, it is to reveal the inadequacy of the methodology to reach what it is that the music is trying to express. Rather than structural coherence or developmental clarity, then, Peters suggests that (at least some) improvised music's goal is the attainment of a state 
of continuous novelty, of becoming-new-again, of re-novation. If what Peters suggests is true, then improvised music amounts to a heuristic enactment of Deleuze's Nietzschean "eternal return of difference," the cut into the future of every present event that creates novelty. 17 What repeats, in collective improvised musical expressions, is difference.

Except in rare cases, the unsociability (or perhaps the Cageian alternative sociability?) of a musical being-alongside is not a willful ignorance of one's co-creators, nor bad faith or sabotage. It is a beingalongside of parallel co-creation, of a manifold process of coding and decoding, of territorializing and deterritorializing that moves along two trajectories: temporally (as the contractions of pasts and futures into manifold living presents) and transversally (as affective impingements or apparatuses of capture). And re-novation is not a radical disengagement with the past, it is a turning toward the opening onto the new, toward the repetition of difference. Therefore, it is through developing an understanding of what transpires in an improvised musical expression that we can more fully understand what it means to repeat difference, which is crucial for understanding temporality, relationality, and subject-formation in music and beyond. Musical expression, then, is an ontological way in. ${ }^{18}$

As I invent within a now-ongoing collective improvisational expression, I make active decisions, but I also let the repetition of habit direct the line of my musical thought (or, better, the repetition of habit directs that line whether I let it or not!). ${ }^{19}$ I compose my musicking self in virtual dialogue with my past: past performances, practice and study, listening and experiencing. ${ }^{20} \mathrm{I}$ am also in a process of composing myself in virtual dialogue with a range of possible futures, the what-I-will-become, which is completely and irreducibly implicated in the what-is-to-become of the musical expression now underway. My future possible self and my now-ongoing I are in an affective relationship, affecting and affected by one another: some bundle of affective forces are products of conscious decisions on my (present) part, but many or most are swirling around below or behind consciousness. My co-creators and -experiencers (those "with" whom I am being) similarly: the result is a multiply-directed, proliferating, constantly reshaping nexus of force-relations: performer to performer, performer to listener, listener to listener, listener (and performer) to music as sonic materiality, musical utterance to musical utterance. ${ }^{21}$

And then there is the relation of subject to self-the relationship that is fractured in the opening-onto-new of Deleuze's third synthesis of time, which assembles proliferating series of events each of which cuts into time and organizes it in new past-future relationalities. If I 
compose myself through the relations in which I find myself, I am always at the same time decomposing myself, deterritorializing myself, enacting an aberrant relationship with myself, queering myself. Machines proceed by breaking down, as Deleuze and Guattari insist. ${ }^{22}$ When I encounter affective flows, they impinge upon my ongoing subject-formation, reterritorializing its dimensional trajectory. Flows are coded in this way: some of the codes that determined the now-justpast state of my ongoing subjectivity are intensified, some interrupted, some redirected. "What is prolonged, what comes to a halt, what is detached, and the different relationships according to which these actions and passions are distributed, help us to understand the formation mechanism of the surplus value of code as an indispensable element of any coding of flows." 23 The ways in which flows are coded in any given instance on $m y$ individuating self are partially determined by my affect attunement, by the ways in which my active and passive pasts have engendered the me that I currently am and am in a process of becoming. ${ }^{24}$ So I will seize and redeploy affective forces in a way that largely reflects my desires, inclinations, and habits.

Machines produce by breaking down - this is the only way machines can be productive. The production of subjectivity proceeds when a machinic coupling interrupts inclinations and habits, creating a rupture that denies any possibility of stasis or continuance. The re-novation that characterizes improvised music reflects the practice of improvising "a life"-my life, as an ongoing process stimulated by multi-directional relationships of multiple ongoing presents and proliferating pasts and futures. ${ }^{25}$

\section{Compose Yourself!}

$$
\begin{array}{r}
\text { time-...(in a sense) proliferating-connection...-(promulgating } \\
\text { connectivity piecemeal) } \\
\text { - - Randall, Compose Yourself }
\end{array}
$$

J. K. Randall begins his provocative, experimental, pedagogical essay Compose Yourself: A Manual for the Young with an epigraph: "What code could I need, or even have any use for, that didn't arise directly from the activity of composing?" 26 Randall's text constitutes a minor gesture within a larger context of analytically oriented music theory, intended to erupt within and at least partially dislodge that practice from its central disciplinary discursive position. ${ }^{27}$ Compose Yourself operates along three concurrent, interpenetrating strata: as music, as a kind of music analysis that locates the reader "right where the musical action really is," and as meta-musicological critique. For Randall, all of 
these practices productively impinge on one another. The sounds of the words and their deployment on the page are musical, with recurring motifs, developmental procedures, counterpoint. The reader is invited through these and other contexts to bring her own set of analytic tools to bear on the text-as-music, which includes imagining new tools appropriate for the radical alterity of Randall's work. At the same time, she is pulled into the world of a creative analytical discourse in itself, one that departs in intent and affect from the dominant discursive models of its time (and, largely, since). Importantly, the reader is changed through this encounter. I find myself decomposing myself through my encounter with Randall's words, as new possibilities proliferate and old codes are deterritorialized.

Example 1 shows an excerpt from the pas de deux from "Lovejoy," the fourth of six "stimulating speculations, stipulating speculation" from Compose Yourself. As with all of Randall's texts, "Lovejoy" is intended to be read simultaneously in the three modes delineated above. First, as music, from two perspectives: as attention to the sonic materiality of the words-their prosody, their timbral and textural valence-and as a "word-composition" that develops in ways that are music-like in terms of things like repetition, concatenation and elision, elongation and truncation, counterpoint of multiple thematic strands, and more. Second, as a form of music analysis that intends to locate the reader right where the musical action is-we might call this a thick description of musical experience or a form of phenomenological engagement. ${ }^{28}$ And third, as what I'll call meta-music-analytic commentary, as a critique of what music analysis is presumed to be for. "Lovejoy," a baseball text-ballet, "unfolds as music might"-a construction that I'll return to below.

In "Lovejoy," two parallel narratives, which we might call inner and outer, run alongside one another in a qualitative differential relation. These unfold as interlocking, co-constituting series, each revealing a new theme latent in the previous. Randall's Borgesian baseball adventure highlights (as Don DeLillo would do later in Underworld, also in a baseball context), the way in which multiple ongoing series of events impinge on, inflect, and redirect one another. Cinematic jump cuts to past and future events fold new layers of detail, new contexts, and new perspectives into present actions. This is brought into stark relief in the pas de deux: we're starting to understand that a seventhinning mini-crisis is underway; our protagonists are up one precarious run, the pitcher is tiring, Ruth's at-bat is imminent, the manager approaches the mound, joined by the infield players, to assess the situation and consider what next steps should transpire. There's a cut in time here. We don't know how this now-unfolding event will play 


\section{V. $\rightarrow$ INEIELD}

(PAs DE deUX)1 The old guy was approaching the infield now, Hornsby walking just a little behind him now, but still to his left. O'Farrell, Les, Tommy, and Sunny Jim, they were all up ahead there at the mound waiting, wondering. (O'Farrell: good. Maybe not the same as bending 'em in to the Reindeer back before the war-back before the deafness and the fainting-spells began to change things. But still: good. The old guy liked O'Farrell. O'Farrell'd been the Reindeer's own choice when the Reindeer'd come to the end of the trail that'd led the old guy and the Reindeer together from Philly to Chicago. And now none of 'em were left in Chicago: the Reindeer wasn't even manager there anymore (and Rabbitt and Moon'd just been fill-ins) and McCarthy was running his WCTU chapter there now and the old guy'd followed O'Farrell to the Cards 'cause Rog was running a ball club instead of a WCTU chapter. Still, after all that travelling, the old guy could've used a couple more days to rest up.-

A couple more years? That's something else. The old guy figured it for a close thing. Needed more and more time to rest up after 9: might not do so good in a fix like this after a couple of years though:

$$
\text { :- be good for } 20 \text { next year though. }
$$

Rog wouldn't be here next year though the way he told 'em all off. Can't tell old Sam your money off the ponies is just as good as his money off his crummy small-loan business. Not after you've told him where to stick those off-day exhibition games during the pennant fight. ' $\mathrm{LI}$ even tell off the Judge if the Judge gets nosey about the ponies. 'LI tell the Judge to quit playing the stock market. It sneaks up on you.

Ruth.

even on

Still, the old guy couldn't help getting a kick out of Rog.)

\section{EXAMPle 1: RANDAll, "LOVEJOY," PAS DE DEUX29}

Used by permission of Open Space. First published in Perspectives of New Music 10/2 (1972)

out, but in the meantime an astonishing proliferation of histories and speculations into possible futures overwhelms the reader's senses: beginning with the fourth-line parenthesis we learn about back-room dealings, gambling, career motivations, individual players' frailties and fears, political machinations, and much more. Randall's creative-but careful and strategic - use of punctuation, parentheses, and brackets intensifies the superposition of past-present flows: there is not one past, there are many, all differently inflecting one another. ${ }^{30}$ The living present of Deleuze's second synthesis of time expresses this multiplicity of pasts, and the cut into the future of each ongoing event in Deleuze's third synthesis of time differently diffracts that multiplicity of pasts, constituting new series of possible futures. ${ }^{31}$ 
And that is how "Lovejoy" becomes music analysis. "Lovejoy's" musical surface is, in one adumbration, a series of now-moments-a relatively conventional story - that one can follow with minimal difficulty. The past themes and future speculations that emerge interspersed throughout its presentation are not merely parenthetical commentary or metamusical hermeneutics; they are clear and compelling illustrations of the way in which any present event is able to express the pasts that condition itincluding pasts that flutter through present experience as passive recollections, impinging on present actions, affecting and affected by them. Deleuze tells us that the virtual past is not static, it is affected by impingements of new expressions in the living present: the present, in this sense, changes the past, and so we have a double movement expressed through the assemblage of living present and dynamically swarming past. Randall's narrative makes this clear. So does music, which seems to be Randall's point: a now-ongoing musical gesture, as a cut in time, expresses a proliferating movement of affective relations with its pasts through the very nature of its cutting into the future. The past of an ongoing musical expression literally changes with the onset of new contextual information: this of course is the point that Schoenberg makes when he describes the addition of a second tone to an unfolding musical context as "mak[ing] the meaning of [a first tone] doubtful." 32

"Lovejoy" unfolds in the midst, in the milieu, drawn by assemblages of multiple ongoing presents and impingements of pasts and futures. "Lovejoy" is in the process of being composed (and hence is a form of improvisation). It is music, about music, and about being about music ("an utterance within, a view about" 33 ). My subjectivity is also in a process of being composed through my experience of reading it-my relationship with "Lovejoy" is affective, composed of imperceptible or barely perceptible affective forces impinging upon and constituting my emergent subjectivity, sliced through by moments of radical "aha!" intensity. Of course every experience is like this: take musical experience, any iteration of which Edward Cone likens to reading a detective story. ${ }^{34}$ Seldom has there been a more obvious paean to the Spinozan/Bergsonian/Deleuzian notion that our subjectivities are drawn through our affective encounters, experiences, and conjunctions. Rahn understands this of course, as he makes clear when he suggests that

to read [Randall] is to experience directly an analog of some timestructural and therefore necessarily musical piece.

Our train ride through time as we read "Compose Yourself" from beginning to end reveals also other paths of succession, quasitemporal, at many levels, intertwining in a multi-dimensional "temporal" counterpoint. Some of these successions are partial orderings, trees or lattices in structure rather than simple orderings. ${ }^{35}$ 
Two crucial points stand out in Rahn's account: (in reverse order) that temporal successions are in fact partial orderings in multidimensional contrapuntal relationships with one another (hence, for example, the present expressing the past while also engendered by it), and that time-structural experience is in fact musical experience. This is a radical reformation of the usual claim that musical experience is a form of temporal experience through which we can learn a great deal about the latter. In this sense, as Rahn suggests, Randall problematizes the musicexperience binary expressly in order to vivify this point. There is nothing in "Lovejoy" that is particularly obviously musical from any conventional perspective, but the way its temporal strands interweave and impinge on one another invites a music-temporal kind of experience, which is a window into understanding how all experience might possibly work: a phenomenological musica naturalis.

To compose myself is already to decompose. Randall's text is didactic in this sense: he is literally asking the reader to engage the text-as music and as meta-musical discourse - in this way, by composing our selves alongside it through continuous, eventful processes of decomposing. Consider the passage shown in Example 2, from "Stimulating Speculation no. 3: Revelstoke". This passage follows the marvelously Deleuzian construct "each focaltime \& . . e each mergingtime ... imposing depth - from before-,by way of after, on now" and precedes another, "(Be

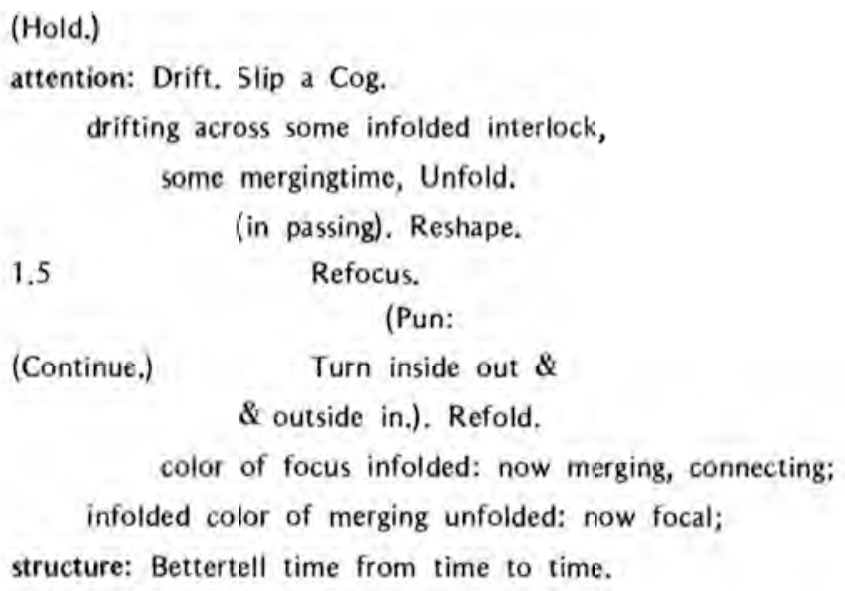


Careful.)-There. (OK.(Fuck it.) (Revise.) Settle Down.) ... Take a chance!... (Advance.) Do it again." 36 The first evocative description resonates with the impingements of past and future on the emergent identity of the (subjective) living present; the second the lively repetition of the Nietzchean dice throw. In between the most vivid description of individuation: unfolding, infolding, refolding; slipping a cog (recall that machines proceed by breaking down); drifting from one's trajectory, from one's time ("time is out of joint" 38 ), only to interlock or merge, to reshape or refocus in a new time, with a new color. The machine breaks down, so what? Revise, roll the dice again. Reshape (recompose, reterritorialize). Refocus on the "infolded color of merging unfolded," refold to engender new connections, new conjunctions, new compositions.

"Revelstoke," is a positioned, perspectival, phenomenologically rich movement/time-image that impinges on our subjectivities such that the most efficacious way to engage it is to re-perform it, as I am doing here. As it unfolds, it invites speculation about the musicality of the text: the sounds of the words (of course), but also their thematic arrangement and development: repeating and extending and truncating and inverting and reversing and eliding motifs. Like "Lovejoy" it offers a mode of analytic engagement: what it feels like to be right there in the middle of an experience and to describe that feeling in terms that are immanent to the experience itself. And it provides a meta-critical commentary on the nature of the relationship of music-writing to its object. Example 3 shows how "Revelstoke" begins.

We see all three registers (music, music-writing, meta-music-writing). And we see ruminations on the double nature of time (as line, as qualitative multiplicity) that will return as a fundamental theme throughout the text. Consider, for example, the passage from a few pages later, reproduced in Example 4. 
(to have been entering the frame inferrably from the right);

(to have been passing leftward);

(to have left the frame inferrably toward the left);

: passing timelessly

, as time might pass,

along a straight line in a single direction;

; emanating

,or at least to have been suffused in, a dull redbrown glow

(-or might it be yellowpurple?; —or would it matter-);

(Anticipate.)

to have convolved time in alternatives of texture:

(Return.)

Something

(-unfolding patch by inconstant patch-)

would have had to have passed

(-emanating in a stretch between purple and yellow-)

across the inconstant, too-slowly lifting darkness:

(Start.)

EXAMPLE 3: "REVELSTOKE" OPENING 39

Used by permission of Open Sprace. First published in Perspectives of Nen Music 10/2 (1972) 


\section{(having drifted- ((Having taken a} chance \&

(\& advanced-

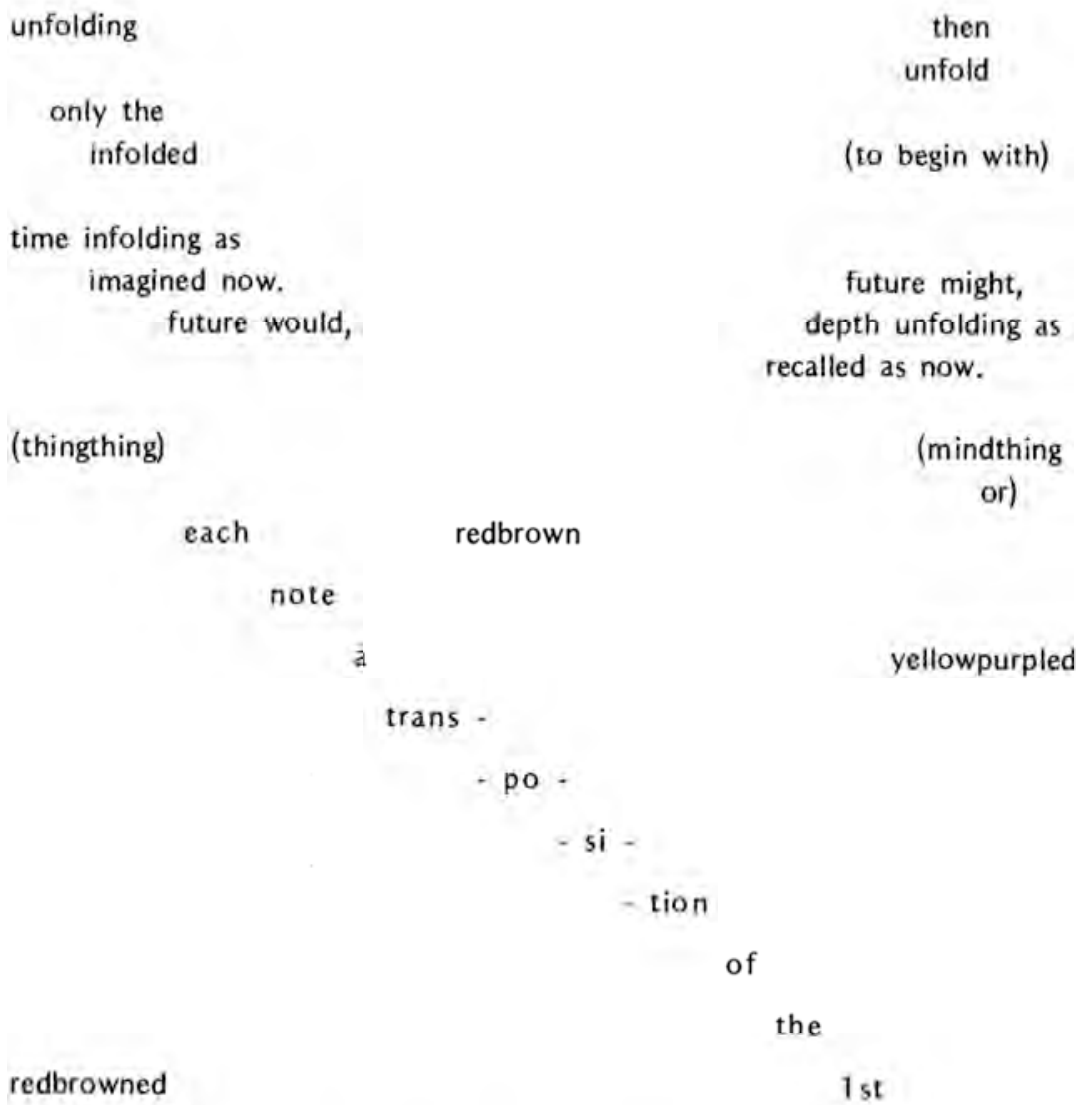

EXAMPIE 4: "REVELSTOKE" P. 45

Used by permission of Open Sprace. First published in Perspectives of Nen Music 10/2 (1972) 
This is a remarkable passage. We get unfolding (time's arrow). We get a double contraction of past and future into the living present ("depth unfolding as recalled as now"). We're asked to distinguish between "thingthing" and "mindthing"—an overtly phenomenological moment: Husserl's motivating claim is that we can't be certain of the status of a thing (a thingthing) but we can be certain of our experience of it (a mindthing). ${ }^{40}$ And then we get this wonderful scalar descent: "each note a transposition of the first." This is at once a resonance with formalist transformational theory's claim that the intervals between pitches can fruitfully be mapped mathematically or geometrically, and a surprising twist: each redbrown note a yellowpurpled transposition of the redbrown first, with the colorful modifiers spatially displaced from the main linear descent; with redbrown somehow transubstantiated into yellowpurple in the same breath. This is a key moment. At once a nod to the formalist music theory that the Princeton school helped animate, a problematization of that formalism by introducing qualitative change into the narrative, and an experiential turn within which qualities swirl and change, unencumbered by positivist claims like " $X$ has the quality of $x$."

The passage continues as shown in Example 5. The compound-melodic nature of this excerpt resists reading aloud, although it's certainly possible to do so. The main point that I would like to foreground here is how Randall elides things (both thingthings and mindthings). There are only events: referrings, befores and afters, infoldings and becomings, focuses and mergings, overlastings and overmasterings, musclings-out, layings-over, decomposings, precomposings. The closest we get to nouns are Deleuzian concerns indeed: time (of course), and trace-the residue, the over-spilling of the affective encounter through which subjectivities are composed. This is an utterly remarkable moment: the Randall of 1970 had surely not encountered Deleuze (few in the US had), and yet here the titular imperative "compose yourself" takes on a multi-registral Deleuzian tone. I compose myself through my affective experiences, which flow from actions in relation to the bodies alongside which I find myself. In the case of this passage these are landscapebodies, or proto-musical-bodies; at any rate the more-than-human bodies that we should continually remind ourselves can count equally in the roster of bodies that we can affect and be affected by. Randall's use of language in "Revelstoke" is also Deleuzian: portmanteaus like "patchspanning" and "ribbonsmooth," "somecolored" and "othercolored" and "samecolored" and "focalcolored"; neologisms like "immerging" and "metattention"; and creative gerunds like "yellowpurpling" that recall Deleuze's "tree greening." 41 And there are proliferations across the page; inviting the reader to read multi-directionally, creatively, to redeploy the concepts that Randall is offering us. 


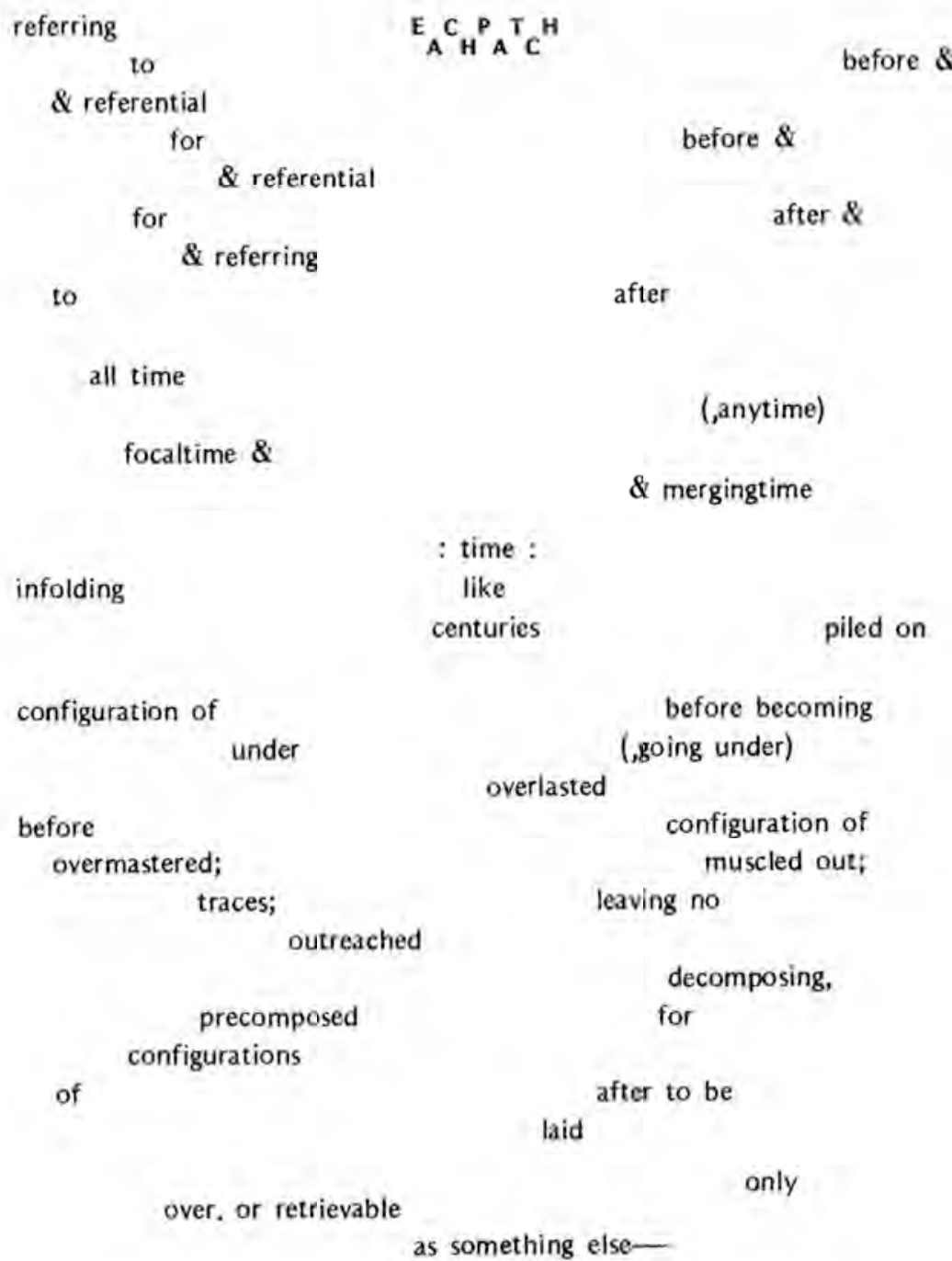

\section{EXAMPLE 5: "REVELSTOKE" P. 46}

Used by permission of Open Space. First published in Perspectives of New Mresie 10/2 (1972). 
My research focuses, in the first register, on temporality-on how time is animated, deployed, or constituted in musical interaction-and in the second, how meaning is produced through those temporally inscribed interactions. This is one reason that Randall's (and Rahn's) texts excite me: see, for instance, the early account in "Revelstoke" shown in Example 6.

(Two things perhaps (-would it have mattered?-):

as Revelstoke

- one, identified by an occasional leftward-passing signpost

- the other, yellowpurpled)

(a timeless morningtime of dull glow Yellowpurpled; of time elapsing by railroad.)

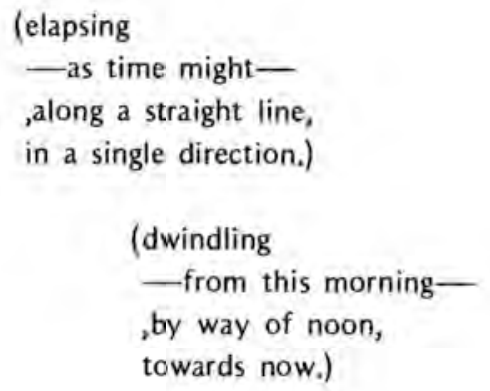

(Hold.)

would have unfolded as music might, imagined in the time of another room.

might have passed

as music would,

unrecalled in an adjacent block of memory.

EXAMPLE 6: "REVEISTOKE" P. 33

Used by permission of Open Space. First published in Perspectives of Nen Music 10/2 (1972) 
In a single gesture, Randall brings together objects of inquiry and the affective relations that bring them into productive dialogue ("two things"; one expressed by a sign in the living present; the other a quality, which we should still consider in terms of its thingness); an admission or revelation that all description of actual events are, ultimately, descriptions of time's unfolding (the putative timelessness of a quality turning out to be, fundamentally, an expression of time's ex-tensity); and a parallel narrative that brings time and the affective events that constitute time into productive proximity to one another (the linear narrative of time elapsing along a straight line folded into an account of the qualitative change that expresses and constitutes time's passing). All of this, as Randall makes clear, is parenthetical, in the service of the first reference to music proper in all of "Revelstoke." Reading outside the parentheses and multiply embedded em-dashes we find that our experience

had solicited coordinates of dimension;

had solicited resolution into functional parts:

a patch of vision

straining to become seen in a stretch of mind bounded by purple and yellow

would have unfolded as music might. . . .

The long parenthetical expression I described just above occurs between "purple and yellow" and "would have unfolded as music might." There is a becoming-music ("time-structural and therefore necessarily musical") of experience unfolding here. My encounter with the fluid, moving world in which I am finding myself is my becomingmusicking, in the sense that there is no music, there is only musicking, as praxis, as what William James and Brian Massumi call a somethingdoing. ${ }^{42}$ For Christopher Small, experiencing music is a mode of musicking. I describe this as the encounter between my human body and, among many other things, the musical-objects-as-bodies that I affect and am affected by. My subjectivity (as becoming-musicking) is being constituted through that encounter. I am becoming-with the music's own becoming, through the more-than of that encounter. 


\section{AfFect-CAPTURE}

In music, "compose" has a specific resonance as an activity, hidden largely from most observation and prior to most musical experience: a composerly experience in this sense is a particular mode of experience open, according to conventional accounts, only to a tiny subset of musicking subjects; perhaps only to the one doing the composing. Composing is often contrasted with improvisation, which, according to these accounts, happens right out in the open, in "real" time. But the work of the archetypal composer-if such a practice can even be distinguished from other kinds of musical activities - is not the only sort of composing relevant to music-making or experiencing. A musicking subject also composes a relationship with a musical expression. Rahn hints at this when he describes his fictitious composer Isobel's ongoing relationship with the process of enacting each next compositional action, as a "particular derivation sequence" producing "her piece-'til-now", all operating alongside the theorization of a "production sequence" or "meta-grammar" of "a kind of finite-state machine." 43 Being-music alongside being-about-music. Extrapolating back into a Deleuzian space, this becomes an affective relationship, a relationship of double capture, a process of assemblage through which the identities of both subjects (experiencer and experience, composer and compositional utterance, as subjects in formation) are transformed. Nothing is ever the same again. "A life" is composed in this way-the event of contact or impingement amounts to a new moment in the ongoing series that constitutes the ever-evolving and -proliferating life of the subject-in-formation. So multiple "activities of composing" are already underway. There is also an imperative implicit in Randall's title: compose yourself! ("Settle Down") Get yourself together (active movements seizing and redeploying transversally-transmitted passive forces), look inward, read those infoldings, those codings and co-occurring decodings, those territorializations and co-occurring deterritorializations.

How do I compose my musicking self, through my improvisational modes of being-with? Deleuze and Guattari, together and individually, offer an array of ways in. Lightly paraphrasing Deleuze, "a great [improviser] is always like a foreigner in the language in which he expresses himself ... At the limit, he draws his strength from a mute and unknown minority that belongs only to him. He is a foreigner in his own language ... he carves out a nonpreexistent foreign language within his own language. He makes the language itself scream, stutter, stammer, or murmur." 44 Randall's triple gambit reflects all of this. But those screams and stutters are, in collective improvisational contexts, 
made alongside other such expressions, emanating from one's coparticipants. Deleuze and Guattari say as much when they clarify the collective nature of minoritarian expression: "there are no possibilities for an individuated enunciation that would belong to this or that 'master' and that could be separated from a collective enunciation. Indeed, scarcity of talent . . . allows the conception of something other than a literature of masters; what each author says individually already constitutes a common action, and what he or she says or does is necessarily political." 45 This of course is not to say there is not "talent" in minoritarian expressions, but rather that what we would describe as such is really an emergent, produced value that reflects the impingements of and within its iterative contexts. We need, therefore, to think of each term of a musical expression "not as a constant in relation to other constants, but as a series of differential positions or points of view on a specifiable dynamism." 46 That dynamism, while perhaps indeed specifiable, is itself in a state of constant transformation as every act of composing is interrupted by a decomposing gesture. The minor that erupts within a major language; the stammer that dislodges understood or expected arcs or flows. The double movement of composition/decomposition proceeds by deterritorializing intensities, and "the composition of deterritorializing intensities is incarnated in abstract machines." 47 Abstract machines, in turn, operate transversally, through heterogeneous couplings and "unnatural nuptials, 'outside the programmed body.'" 48 I can only compose myself alongside, passively affected by and affecting, others.

Erin Manning describes the more-than as an affirmation of difference, of the variation felt at the edges of relational experience, of the minor gestures that continually decompose performative acts even as they are being enacted. ${ }^{49}$ Like Manning, I assert that to think in terms of this double movement is to take an ethical position in which the boundary between what we might call, even creatively and affirmatively, a subject and the others the subject affects and is affected by becomes productively porous. Identities, from this affective perspective, unfold as expressions of relationships, impingements, movements. My composing/decomposing, territorializating/deterritorializing (sonic) self situates alongside and interacts fundamentally with a network of other selves, human and otherwise, all impinging on one another in complex arrays of affective relationships, all engaging in multiply-directed acts of capture. Identity, therefore, is a practice of becoming-with as much as it is a process of becoming-other. To becomewith is a political action-Manning calls this "choreographing the political"; Guattari theorizes a group-subject, not a group of subjects, 
but a proliferating singularity constituted by (political) encounters. 50 Somewhere in this concept-space the seeds of a theory of improvisational interaction stir.

A musical event occurs. Affective forces pass-some are captured, to be redeployed as actual components of new events. Others remain virtual-part of a new past, itself transformed through those impingements. That past amounts to a new bundle of virtual forces with the potential to impinge on a new constellation of presents. Everywhere in Deleuze and Guattari's thought such movement transpires: to affect and to be affected; double capture. The emergentsubjective space of the now-ongoing musical performance, through this ongoing series of double captures, is a process of what Deleuze and Guattari call heterogeneous nuptials - not of two co-determining partners (orchid-wasp or man-wolf) but of a multiplicity of bodies: performing bodies, listening bodies, musical-objects-as-bodies, each drawn through the singularities of its pasts, each with an opennessonto-future that is partially determined by its past but also subject to radical rupture based on the degree to which it captures or is captured by the bodies with which it interacts. 51 These are all molecular bodies, then, each necessarily in a process of becoming-other. Become what? In our little musical scenario, becoming musicking bodies.

For example, a musical event might occur as the product of a performer's active choice, expressing the impingements of all number of past, concurrent, and future force-relations. ${ }^{52}$ The way in which I fold my experience of that event into my own process of individuation expresses my own constellation of pasts and my own affective attunement. What is important here, what brings Deleuze's affective account into dialogue with Peters's Heideggerian one, is that the way I fold that experience into my ongoing subject-formation need not correspond with the intention or desire of the participant who produced that which I am experiencing. 53 A call can engender any sort of response. Furthermore, if I am an active participant, my expression of that infolding has the potential to deterritorialize my co-participant's ongoing self-composition. And on it goes, proliferating in all directions. The event of the musical utterance, the event of my experience of it, and the event of my expression of the transversal coupling (the sonic body of the musical utterance; its utterer; me) are distinct, but all implicated in one another.

Each musicking subject is "defined by the states through which it passes"; each state leaves a trace on the subject-perhaps imperceptible, perhaps momentous. Deleuze and Guattari put this another way: "the subject is born of each state in the series, is continually reborn of 
the following state that determines him at a given moment, consumingconsummating all these states that cause him to be born and reborn."54 The subject is born anew with each new passing-through, expressing codes passed on from earlier states and absorbed from concurrent ones. What counts as a state in this account? A state is the nowongoing product of the production of production: what is now in the process of being produced through acts of machinic assemblage. So a state is itself an action, an event. To say that the subject is born anew is to reiterate Deleuze's thematization of difference: to be born anew is a radical transformation: a big event the experience of which demonstrates that what was will never again return; that the only thing that returns eternally is difference, newness. But Deleuze has also shown us that every event marks a cut through which what was will never return. So a rebirth, radical as it sounds, is really just a pointed way to show that through its passing-through of a state, and the impingement of the actions that constitute that state, and the residue those impingements leave, the subject is ever new. And that ever-newness describes what the subject is - it is formed precisely through those passings-through, through the traces left on it by those states: there is no subject outside of this process of relationship-forming.

\section{BeCOMING-With}

To compose yourself is to compose a body with that with which you are in the process of becoming. You are not becoming other than what you are (since what you are is an ongoing process of actual-virtual impingements, the virtual also real), but what you are is the product of the process. Becoming the musicking body of this ongoing series of acts of musical expression. This process is one of molecular impingements and emissions, of transversal relations, of transcoding. As I compose my musicking self, in the moment of improvisational interaction, it is the proximities of co-composing bodies, the intensities that swirl between them, and the degrees and kinds of affective attunements that determine the singular nature of any particular stage in the process, any particular moment in the series. Forces are captured and redeployed. Subjectivity (that which is being composed and decomposed) is the surplus, the residue of these force-encounters. "Wherever there is transcoding, we can be sure that there is not a simple addition, but the constitution of a new plane, as of a surplus value." 55 Addition suggests that there is a fixed subject that is transformed, that there is an $x$ to which the force of an encounter adds $\mathrm{a}+1$. But the constitution of a 
new plane-immanent to itself as an ever-differentiating life-is a continually creative practice through which virtual and actual inflect one another; virtual-becoming-actual; actual opening new lines for virtual forces to emerge. New plane, same as the old plane-what returns eternally is difference. This is a dimensional mathematics, a qualitative multiplicity irreducible to numbers. ${ }^{56}$ Anne Sauvagnargues describes assemblages similarly: "they are positioned precisely in the interstices of components that they deterritorialize by connecting." 57

The transversal nature of all of this, operating within and creating a relational ecology, is what Deleuze and Guattari mean by involution. "Becoming is involutionary, involution is creative." 58 This is evolution by symbiosis; of "composing . . . a body without organs defined by zones of intensity or proximity"; of becoming-with (alongside, in relation to, affecting and affected by) the bodies and relations that constitute one's ecological context; of implicating oneself in the creation of a plane of immanence. Mark Hansen refers to the "dissolution of form" this entails, and the "heterogeneous molecular activity" that animates it. ${ }^{59}$ If involution amounts to a dissolution of form that proceeds through transversal molecular movements, then the re-novation of musical improvisation is an ideal space to begin to understand how it operates. I play a gesture-again, a product of a complex constellation of codings and decodings that expresses my histories and the molecular impingements of transversal forces and cocomposing bodies. The sonic materiality of this gesture-an affected/ affecting body-impinges on your now-ongoing musical expression, interrupting its (and your-they are different) process of coding, forming a new machine by causing the previous one to break down. We each have a new-individual-perspective on the ongoing collective musical expression, as does anyone who happens to be there to hear it or who is participating in making it happen. The process goes on: the identity of the ongoing performance is in formation; the identities of the participants likewise. There is only becoming, but there is no becoming without becoming-with.

A coding can be a deterritorialization (and likewise a decoding a territorialization 60 ), in fact, we might go so far as to say a coding is a deterritorialization, so far as every act of coding involves temporallyunfolding ruptures through which the new is produced. My affect attunement is a condition for certain sorts of codings, but those codes are enacted through the transversal, heterogeneous molecular activity of my becoming-with. This, according to Deleuze and Guattari, is the starting point for understanding pretty much everything, from the nature of time to subjectivity to political relationality. What improvised 
music does, if Gary Peters is correct, is shine a light on the process of re-novation that steers all existence, offering, perhaps, a range of modes of engagement through which we can practice becoming-other. Jack Halberstam offers a similar recipe for praxis: "under certain circumstances failing, losing, forgetting, unmasking, undoing, unbecoming, not knowing may in fact offer far more creative, more cooperative, more surprising ways of being in the world."6l I'll unpack the implications of Halberstam's marvelous list in another essay, but I want to draw out a connection between undoing and decomposing oneself, in the at least metaphorically musical sense in which composition (doing) involves the invention of some kind of syntax or rules of engagement (assembling with a larger history of syntactic practice) that is undone by acts of decomposing involving creating disjunctions or stammers. "Unbecoming" likewise. And perhaps most surprising, the notion that this creates new spaces for cooperation, that being-with is creative and cooperative (and transversal and heterogeneous), if not in pursuit of a common work-drive. 
Notes

1. James K. Randall, to whom I will turn shortly, makes this particularly explicit. See for example this revelatory statement in an interview with Dorota Czerner, transcribed in Gleason (2013a, 249):

... I remember that in working to describe music well, and as I think I've said plenty I was a real fanatic for analyzing music but that at the same time feeling that, "gee wait a minute, I haven't yet found a way that's really getting at what this is going on," so that caused me not only to write a little funny but to write sometimes with the conscious idea that, wait a minute, how about writing like music, instead of writing about music.

Gleason goes on to multiply this concept, providing a vivid analysis of aspects of Randall's text that we might call "writing like Randall's meta-musical discourse, instead of writing about Randall's meta-musical discourse."

2. Rahn ([1989] 2001, 86).

3. Rahn ([1979] 2001, 59-60).

4. Rahn $(2004,132)$.

5. Rahn $(2007,60)$.

6. “We could quibble with Lewin's basic formulation, too, as taking some given (or found) thing and changing it into some other like thing. It seems altogether too focused on things. It may be an advance to think, as Lewin does, in terms of the transformation from one thing to the other, but the underlying granulation is rather grating. We want to think of music as growing. The thingness of music might lie in the magic metamorphosis from one thing, the music up to now . . . to a new and larger thing which is quite different, voilà, hey presto. Lewin-things are typically the same size, so they do not grow, and the transformations are structure-preserving, which means we are not surprised by the new thing because it is not really different." (Rahn 2007, 58-59).

7. Peters $(2009,17)$.

8. Rahn ([1993] 2001, 8). 
9. Boretz ([1992] 2003, 338).

10. Christopher Small makes a similar point when he defines musicking as "[taking] part in a musical performance, not just as performer but also as listener, or as provider of material for performance-what we call composing-or in any other way, [such as] dancing ... [or] taking tickets at the door or shifting the piano around. . . Musicking is something that people do together; all those present are taking part in it, and the fact that one verb covers everything that is going on in the performance space means that it recognizes no essential difference between what the performers are doing and what the rest are doing." (Small [1990] 2016, 88).

11. See Deleuze and Guattari (1983; 1987). Deleuze and Guattari's concept of machinic coupling evolved over the course of their collaboration, beginning with productive assemblages of bodies to the Body without Organs, proceeding to an abstract coupling of bodies to bodies in the formation of a $\mathrm{BwO}$; in all cases the coupling or assemblage is a deterritorializing act that produces new flows, new codes, new strata (and ruptures existing ones). I find the radically productive potential of the body-to-body assemblage particularly fruitful for thinking through the relations between human, post- or prosthetic human (as in humaninstrument assemblages), and non-human (as in the sonorous stuff of musical expression, as a body or bodies); see Stover (2018b).

12. The concept of non-human agents is the driving theme of Karen Barad's "new materialist" thought; see Barad (2007).

13. This is a primary theme that threads through Peters 2009). See, for example, pp. 53-55 on "negative" versus "positive" improvisation (following Isaiah Berlin's negative and positive freedoms), which also engages the efficacy of aesthetic alternatives to Kant's/Schiller's "form-drive."

14. Heidegger (1962, 162); also in Peters (2009, 172nl3).

15. Simon Critchley often made this point in courses that I took with him at The New School.

16. Peters $(2009,81-84)$.

17. For more on Deleuze's engagement with Nietzsche's eternal return, see Deleuze (1983, 25-28ff) and Deleuze (1994, 40-41, $89-92)$. 
18. As Rahn makes clear, however, musical expression is not a perfect stand-in for the complex openness of an actual human, relational life. "Music's essential deceit is its ability to encapsulate itself in . . . a temporal subworld, which Mary can live alongside her life and learn from, but which is bounded (however complex) and therefore is a thing. Mary's world, Mary's life, is not a thing. It is ultimately ungraspable because unbounded, always tending to a whole-to-that-time but never a whole" (Rahn [1993] 2001, 1718). Still, there is an important heuristic value in dealing with something comparatively small and comparatively well-contained like a musical expression; in addition, I would argue that improvised music does the job better than do composed works.

19. Habit (constituting a habitude) plays a crucial role in Deleuze's first synthesis of time; see for example Deleuze (1994, 73-74): "Habit draws something new from repetition-namely, difference (in the first instance understood as generality). In essence, habit is contraction. Language testifies to this in allowing us to speak of 'contracting' a habit, and in allowing the verb 'to contract' only in conjunction with a complement capable of constituting a habitude. . . Passive synthesis . . constitutes our habit of living, our expectation that 'it' will continue ... thereby assuring the perpetuation of our case. ... It is simultaneously through contraction that we are habits."

20. See Stover $(2017$, I2.15-2.19).

21. I develop this last point in Stover (2016; 2018a).

22. "Desiring-machines work only when they break down, and by continually breaking down" (Deleuze and Guattari 1983, 8). This is a foundational theme in Deleuze and Guattari's work: desiringmachines are "formative machines, whose very misfirings are functional, and whose functioning is indiscernible from their formation"; they "proceed by breaks and flows" (Deleuze and Guattari 1983, 286-87); "it is a question of a model that is perpetually in construction or collapsing, and of a process that is perpetually prolonging itself, breaking off and starting up again" (Deleuze and Guattari 1987, 20). They likewise assert that "the plane of consistency is constantly extricating itself from the plane of organization, causing particles to spin off the strata, scrambling forms by dint of speed or slowness, breaking down functions by means of assemblages or microassemblages" (Deleuze and Guattari 1987, 270). I suggest that the concept of breaking down, as a 
basic ontogenic principle, is traceable to Deleuze's notion of the fractured self that animates the third synthesis of time in Difference and Repetition as much it is to Guattari's schizoanalytic project.

23. Deleuze and Guattari (1983, 164).

24. I borrow the term "affect attunement" from Brian Massumi, who in turn coopted it from psychologist Daniel Stern. See Massumi $(2011,114)$.

25. See Deleuze (2005).

26. Randall ([1972] 1995, 1). Randall is quoting composer Al Daniels from a conversation the two had.

27. This theme threads through Scott Gleason's extended engagement with "Princeton Theory." See Gleason (2013b, 49-50ff).

28. See Gleason (2013b, 93-96).

29. Randall ([1972] 1995, 74).

30. Rahn notes this as well, describing not only Randall's punctuation and bracketings but his typefaces, word placements, and moresee Rahn ([1979] 2001, 56-57).

31. See Stover $(2017$, I $2.1-2.8)$ for a detailed musical contextualization of Deleuze's three syntheses of time.

32. Schoenberg $(1975,123)$.

33. Boretz ([1978] 2003, 1).

34. Cone (1977). I should probably temper this statement slightly by saying that "from a Deleuzian perspective, every experience is like this"-this is the most important takeaway from Deleuze's presentation of his third synthesis of time; see Deleuze (1994, 89-91).

35. Rahn ([1979] 2001, 56).

36. Randall ([1972] 1995, 41, 43).

37. Randall ([1972] 1995, 42).

38. Deleuze borrows this famous line from Hamlet via Hölderlin, in order to frame the radical cut of his third synthesis of time-see Deleuze (1994, 88-89).

39. Randall ([1972] 1995, 31).

40. See, for example, Husserl (1970, 104-05). 
41. Deleuze $(1990,6)$.

42. See Massumi $(2011,27)$.

43. Rahn $(2007,71)$.

44. Deleuze (1998, 109-10).

45. Deleuze and Guattari (1986, 16).

46. Deleuze (1998, 108-09).

47. Guattari $(1995,38)$.

48. Deleuze and Guattari $(1987,273)$.

49. Manning (2016).

50. Manning (2016, 128). In his Introduction to Guattari's Psychoanalysis and Transversality, Deleuze defines group-subjects "by coefficients of transversality that ward off totalities and hierarchies. They are agents of enunciation, environments of desire, elements of institutional creation” (Guattari 2015, 14).

51. See the plateau “10,000 B.C.: The Geology of Morals (Who Does the Earth Think It Is?)" (Deleuze and Guattari 1987, 39-74) for more on the double articulation of subjectifying forces.

52. See Stover (2018a) for an extended engagement with Deleuze's concept of affective force-relations.

53. I thank Scott Gleason for calling attention to the crucial political implications of this point. See, for example, Nancy $(2017,50-51)$.

54. Deleuze and Guattari $(1983,20)$.

55. Deleuze and Guattari $(1987,314)$.

56. Deleuze $(1988,38-43)$.

57. Sauvagnargues $(2016,192)$.

58. Deleuze and Guattari $(1987,238)$.

59. Hansen $(2000,923)$.

60. See Deleuze and Guattari $(1987,54)$. "There is no simple correspondence between codes and territorialities on the one hand and decodings and deterritorialization on the other: on the contrary, a code may be a deterritorialization and a reterritorialization a decoding."

61. Halberstam $(2011,2-3)$. 


\section{REFERENCES}

Barad, Karen. 2007. Meeting the Universe Halfway: Quantum Physics and the Entanglement of Matter and Meaning. Durham, NC: Duke University Press.

Boretz, Benjamin. [1978] 2003. "Language, as a Music: Six Marginal Pretexts for Composition: Thesis." In Being About Music: Textworks 1960-2003, 2: 1-17. Red Hook, NY: Open Space.

. [1992] 2003. "Experiences With No Names." In Being About Music: Textworks 1960-2003, 2: 338-52. Red Hook, NY: Open Space.

Cone, Edward T. 1977. "Three Ways of Reading a Detective Story-Or a Brahms Intermezzo." The Georgia Review 31/3: 554-74.

Deleuze, Gilles. 1983. Nietzsche and Philosophy. Trans. Hugh Tomlinson. London: Athlone.

- 1988. Bergsonism. Trans. Hugh Tomlinson and Barbara Habberjam. New York: Zone Books.

. 1990. The Logic of Sense. Trans. Mark Lester. New York: Columbia University Press.

. 1994. Difference and Repetition. Trans. Paul Patton. New York: Columbia University Press.

. 1998. Essays Critical and Clinical. Trans. Daniel W. Smith and Michael A. Greco. London: Verso.

- 2005. "Immanence: A Life." In Pure Immanence: Essays on A Life, trans. Anne Boyman, 25-34. New York: Zone Books.

Deleuze, Gilles, and Félix Guattari. 1983. Anti-Oedipus: Capitalism and Schizophrenia. Trans. Robert Hurley, Mark Seem, and Helen R. Lane. Minneapolis: University of Minnesota Press.

. 1986. Kafka: Toward a Minor Literature. Trans. Dana Polan. Minneapolis: University of Minnesota Press.

- 1987. A Thousand Plateaus: Capitalism and Schizophrenia. Trans. Brian Massumi. Minneapolis: University of Minnesota Press.

Gleason, Scott. 2013a. "Improvising Compose Yourself." Current Musicology 95: 247-57.

2013b. "Princeton Theory's Problematics." PhD diss., Columbia University. 
Guattari, Félix. 1995. Chaosmosis: An Ethico-Aesthetic Paradigm. Trans. Paul Bains and Julian Pefanis. Bloomington: Indiana University Press.

2015. Psychoanalysis and Transversality: Texts and Interviews 1955-71. Trans. Ames Hodges. South Pasadena, CA: Semiotext(e).

Halberstam, Judith. 2011. The Queer Art of Failure. Durham, NC: Duke University Press.

Hansen, Mark. 2000. "Becoming as Creative Involution?: Contextualizing Deleuze and Guattari's Biophilosophy." Postmodern Culture $11 / 1$.

Heidegger, Martin. 1962. Being and Time. Trans. John Macquarrie and Edward Robinson. New York: Harper \& Row.

Husserl, Edmund. 1970. The Crisis of European Sciences and Transcendental Phenomenology. Trans. David Carr. Evanston: Northwestern University Press.

Manning, Erin. 2016. The Minor Gesture. Durham, NC: Duke University Press.

Massumi, Brian. 2011. Semblance and Event: Activist Philosophy and the Occurrent Arts. Cambridge, MA: MIT Press.

Nancy, Jean-Luc. 2017. The Possibility of a World. Trans. Travis Holloway and Flor Méchain. New York: Fordham University Press.

Peters, Gary. 2009. The Philosophy of Improvisation. Chicago: University of Chicago Press.

Rahn, John. [1979] 2001. "Aspects of Musical Explanation.” In Music Inside Out: Going Too Far in Musical Essays, 51-68. Amsterdam: $\mathrm{G}+\mathrm{B}$ Arts International.

-. [1989] 2001. "New Research Paradigms." In Music Inside Out: Going Too Far in Musical Essays, 83-99. Amsterdam: G+B Arts International.

- [1993] 2001. "Repetition." In Music Inside Out: Going Too Far in Musical Essays, 7-19. Amsterdam: G+B Arts International.

- 2004. "The Swerve and the Flow: Music's Relationship to Mathematics." Perspectives of New Music 42/1: 130-48.

- 2007. "Approaching Musical Actions." Perspectives of New Music 45/2: 57-75. 
Randall, James K. [1972] 1995. Compose Yourself: A Manual for the Young. Red Hook, NY: Open Space.

Sauvagnargues, Anne. 2016. Artmachines: Deleuze, Guattari, Simondon. Trans. Suzanne Verderber and Eugene W. Holland. Edinburgh: Edinburgh University Press.

Schoenberg, Arnold. 1975. "New Music, Old Music, Style and Idea." In Style and Idea. Ed. Leonard Stein. Trans. Leo Black. Berkeley: University of California Press.

Small, Christopher. [1990] 2016. "Whose Music Do We Teach Anyway?" In The Christopher Small Reader, ed. Robert Walser, 87-94. Middletown, CT: Wesleyan University Press.

Stover, Chris. 2016. "Musical Bodies: Corporeality, Emergent Subjectivity, and Improvisational Spaces." M/C Journal 19/1.

- 2017. “Time, Territorialization, and Improvisational Spaces." Music Theory Online 23/1.

Music 55/2: 5-66.

- 2018b. "Affect, Play, and Becoming-Musicking." In Deleuze and Children, ed. Markus Bohlmann and Anna Hickey-Moody, 145-62. Edinburgh: Edinburgh University Press. 